\title{
Substrate and water adsorption phenomena in a gas/solid enzymatic reactor
}

\begin{tabular}{|c|c|}
\hline Journal: & Biotechnology Journal \\
\hline Manuscript ID: & BIOT-2008-0291.R2 \\
\hline Wiley - Manuscript type: & Research Article \\
\hline $\begin{array}{r}\text { Date Submitted by the } \\
\text { Author: }\end{array}$ & 17-Mar-2009 \\
\hline Complete List of Authors: & $\begin{array}{l}\text { Dimoula, Kerasina; RWTH Aachen University, Aachener } \\
\text { Verfahrenstechnik - Biochemical Engineering } \\
\text { Pohl, Martina; Heinrich Heine University Duesseldorf, Institute of } \\
\text { Molecular Enzyme Technology-Research Center Jülich } \\
\text { Büchs, Jochen; RWTH Aachen University, Aachener } \\
\text { Verfahrenstechnik - Biochemical Engineering } \\
\text { Spiess, Antje; RWTH Aachen University, Aachener } \\
\text { Verfahrenstechnik - Biochemical Engineering }\end{array}$ \\
\hline Keywords: & $\begin{array}{l}\text { gas/solid biocatalysis, thermodynamic activity, alcohol } \\
\text { dehydrogenase, adsorption, adsorption isotherm }\end{array}$ \\
\hline
\end{tabular}

\section{s scholarONE" \\ Manuscript Central}




\title{
$\underline{\text { Research Article }}$
}

\section{Substrate and water adsorption phenomena in a gas/solid enzymatic}

\author{
reactor
}

5 Kerasina Dimoula ${ }^{1}$, Martina Pohl ${ }^{2}$, Jochen Büchs ${ }^{1}$, Antje C. Spiess ${ }^{1}$

1. RWTH Aachen University, Aachener Verfahrenstechnik - Biochemical Engineering

2. Institute of Molecular Enzyme Technology, Heinrich Heine University Düsseldorf, Research Centre Jülich

10

Keywords: gas/solid biocatalysis, thermodynamic activity, alcohol dehydrogenase, adsorption, adsorption isotherm

Corresponding author: Antje C. Spiess, Dr.-Ing.; RWTH Aachen University; 15 Aachener Verfahrenstechnik - Biochemical Engineering; Worringer Weg 1, 52074 Aachen Germany

Antje.Spiess@avt.rwth-aachen.de;

Tel: +49 / $241 / 80-28111$

Fax: +49 / $241 / 80-22570$ 


\section{Abbreviations}

$\begin{array}{lll} & \text { 2-prop } & \text { 2-propanol } \\ & \text { AcPh } & \text { acetophenone } \\ 25 & \text { BSA } & \text { Bovine serum albumin } \\ & \text { IU } & \text { international unit } \\ & \text { LBADH } & \text { Lactobacillus brevis alcohol dehydrogenase } \\ & \text { RH } & \text { relative humidity } \\ & \text { SEM } & \text { scanning electron microscopy } \\ 30 & \text { YADH } & \text { yeast alcohol dehydrogenase }\end{array}$




\begin{abstract}
35 The adsorption of water and substrates to dry deposited alcohol dehydrogenase from Lactobacillus brevis (LBADH) is studied in a continuous enzymatic gas/solid reactor. This work is aiming at obtaining a deeper and more thorough understanding of the enzyme microenvironment in the gas/solid system of acetophenone reduction with concomitant oxidation of 2-

40 propanol. Extensive water adsorption studies showed that the effect of sucrose in the enzyme preparation on the water adsorption isotherm is significant for water activities exceeding 0.5 and reaches a factor 2 with respect to bead mass at $a_{w}=0.9$. Significant hysteresis during water desorption is identified, resulting $\mathrm{g}$ in up to $0.6 \mathrm{mg} \mathrm{water} / \mathrm{mg}_{\mathrm{protein}}$, for lyophilized 45 enzyme preparation and up to $10 \mathrm{mg}$ water $/ \mathrm{mg}_{\text {protein }}$ for deposited enzyme preparation The adsorption of the substrates is quantified here for the first time. Whereas the adsorption of the main substrate, acetophenone, may reach a significant level of up to $6 \mathrm{mg} / \mathrm{mg}_{\text {protein, }}$ at an acetophenone activity of 0.32 , the secondary substrate, 2-propanol is not adsorbed at a detectable

50 degree. The presence of water leads to a decrease of the adsorbed amount of acetophenone, by approximately $25 \%$, at a water activity of 0.54 .
\end{abstract}




\section{Introduction}

55 Gas/solid biocatalysis has been shown to have various potential applications, including fine chemical synthesis [1] and toxic pollutant degradation [2]. Furthermore gas/solid biocatalysis constitutes an efficient tool to understand the effects of the microenvironment of the biocatalyst on its activity and stability [3].

60 The thermodynamic activity is used to quantify the availability of water and substrates to the biocatalyst in non-conventional media. In the case of organic solvents, the calculation of the thermodynamic activities of the compounds requires the prior knowledge of the activity coefficients. On the contrary, for gas/solid systems, where the gas phase can be assumed as

65 ideal, the thermodynamic activity $a_{i}$ is calculated in a more straightforward manner. It is given by $a_{i}=\frac{p_{i}}{p_{i}^{s}}$, where $\mathrm{p}_{\mathrm{i}}$ is the partial pressure of a compound $\mathrm{i}$ and $\mathrm{p}_{\mathrm{i}}^{\mathrm{s}}$ is the saturation pressure of this compound at the operating temperature. The partial pressures of the different compounds of the reaction mixture can be adjusted separately. Thus, independent control of the

70 thermodynamic activity of each compound present in the microenvironment of the biocatalyst is achieved. This constitutes the major advantage of the gas/solid system, as a fundamental research tool [3]. 
The water activity $\left(a_{w}\right)$ specifically is a key parameter in non-conventional biocatalysis. The role of water during biocatalysis is multifaceted. Water is a 75 substrate or product of a hydrolytic or synthetic reaction, respectively. For any reaction water can act either directly on the structure of the enzyme or as solvent facilitating the diffusion of the reactants. The water adsorption isotherm is used to describe the state of the water present in the microenvironment of the biocatalyst [4]. The dependency of enzyme activity

80 on the water activity in the gas/solid systems has already been demonstrated [5-8].

A typical water adsorption isotherm (Fig.1) shows two characteristic break points, A and B. Point A corresponds to the water activity level below which the water is highly structured and forms the first hydration layer (water 85 monolayer) of the dried enzyme. The intercept with the $y$-axis at $a_{w}=0$ corresponds to the tightly-bound water amount. Between points $A$ and $B$, the water content changes in a linear fashion with increased $a_{w}$, resulting in the formation of subsequent hydration layers. Point B denotes the water activity level above which free water appears [4].

90 Like water, any other compound present will compete for adsorption sites on the biocatalyst $[2,3]$. While previous studies have focused exclusively on the adsorption of water equilibrating with the solid phase and the resulting effect on the enzyme activity and stability, there are no studies so far dedicated to the adsorption of substrates to the enzyme. There have been studies 
95 addressing the substrate adsorption [9] or the possible product adsorption [10], without further quantification. In an effort to fill this gap, the present work focuses on the investigation of the adsorption of substrates on the biocatalyst, taking place in parallel or in competition to the water adsorption.

In order to be able to interpret the results, a well characterized reaction [11]

100 was chosen: the conversion of acetophenone, catalyzed by the Lactobacillus brevis alcohol dehydrogenase (LBADH) deposited onto non-porous glass carriers together with the cofactor NADPH. In order to overcome the limitations posed by the batch measuring methods used in the past [12-14] and to mimic the conditions of the gas/solid system, the adsorption

105 measurements in our study are performed in a continuous gas/solid system, as proposed previously [2].

Initially, the water adsorption on the enzyme preparation is quantified indicating the effect of sucrose on the adsorption isotherm. Moreover, the adsorption of the two reaction substrates, namely acetophenone and 2-

110 propanol, is investigated and quantified. The competitive adsorption, with respect to the water presence influence on the substrates adsorption, is also studied.

\section{Materials and Methods}




\subsection{Enzyme}

Purified and lyophilized wild type LBADH expressed in E. coli was obtained from Liliya Kulishova, Institute of Molecular Enzyme Technology (IMET) at

120 Research Center Jülich according to B. Riebel, 1996 (PhD thesis, HeinrichHeine Universität Düsseldorf, Germany). The resulting lyophilized enzyme had a concentration of $0.4 \mathrm{mg}_{\text {protein }} / \mathrm{mg}_{\text {solid, }}$ the rest being salts resulting from the buffers (10 mM triethanolamine (TEA) adjusted to $\mathrm{pH} 7$ using $\mathrm{HCl}$ and 1 $\mathrm{mM} \mathrm{MgCl} 2$ ) used during the purification process, and a specific activity of 88

$125 \mathrm{IU} / \mathrm{mg}_{\text {protein. }}$

\subsection{Chemicals}

Acetophenone and 2-propanol were of $>98 \%$ purity and purchased from Fluka (Germany). All other chemicals were of analytical grade and obtained 130 from Roth (Germany). Bradford reagent and BSA were obtained from Bio$\operatorname{Rad}($ USA).

\subsection{Deposition procedure}

Applying a variation of the deposition procedure described in [15], $170 \mathrm{IU}$ of

135 lyophilized enzyme, sucrose (5 times enzyme mass) and NADPH (12 times molar enzyme amount), were dissolved in $1 \mathrm{~mL}$ phosphate buffer ( $\mathrm{l}=50 \mathrm{mM}$ and $\mathrm{pH}$ 7, resulting from $\mathrm{KH}_{2} \mathrm{PO}_{4}$ and $\mathrm{Na}_{2} \mathrm{HPO}_{4}$ solutions) and mixed together 
with $500 \mathrm{mg}$ washed with distilled water and dried glass beads $0.25-0.3 \mathrm{~mm}$ (Sartorius, Germany) for 30 minutes in a rotary mixer (RMSW, Welabo, 140 Germany) at $4^{\circ} \mathrm{C}$. The mixture was dried at $4^{\circ} \mathrm{C}$ in a desiccator, containing Silica Gel Orange 2-5 mm (Carl Roth $\mathrm{GmbH}$, Germany), with a vacuum pump (CVC 200II, Vacuubrand, Germany) at 300 mbar for 4 hours and successively at 40 mbar until dry, and enzyme was partly deposited to the carriers' surface, while some amount was lost on the immobilization vessel walls. The enzyme 145 preparations were stored at $4^{\circ} \mathrm{C}$.

\subsection{Protein loading determination}

In order to determine the amount of protein immobilized on the carriers a Bonde test was carried out [16]. An amount of $10 \mathrm{mg}$ of beads with 150 immobilized enzyme were weighted into a cuvette and $800 \mu \mathrm{L}$ TEA buffer as well as $200 \mu \mathrm{L}$ Bradford reagent were added to the beads and mixed thoroughly. After incubation of $5 \mathrm{~min}$ and settling of the beads, the absorbance of the solution was measured at $465 \mathrm{~nm}$ by means of a UV-VIS spectrophotometer (UNIKON 922, Kontron Instruments, Italy). The protein

155 amount immobilized on the beads was calculated using a BSA calibration curve.

\subsection{Water adsorption measurement unit}


The measurement of the water adsorbed by the deposited enzyme 160 preparation was performed in a water adsorption unit (Fig.2) which has an operation principle very similar to that of the gas/solid reactor [17]. Prior to this measurement, the enzyme preparation was dried by means of a pure $\mathrm{N}_{2}$ stream until a totally dried enzyme preparation was obtained. Two dried, by means of a humidity trap (MT200-2, Agilent Technologies, Germany),

165 nitrogen streams were defined by mass flow controllers (F201C-FB-11-V, Bronkhorst Mättig GmbH, Germany) and directed to a thermo stated unit (WTB, Binder GmbH, Germany). One of the two streams was equilibrated with water in two successive water flasks. This stream was then mixed in a mixing chamber with the second stream of pure nitrogen to generate a

170 mixture with total volumetric flow rate of $15 \mathrm{~mL} / \mathrm{min}$. This gas mixture was first directed through the bypass of the packed bed, until a constant humidity level was measured by a humidity sensor (D07P-EE22, E+E Elektronik GmbH, Germany). Then, the mixture was directed through the packed bed, containing a specific amount of immobilized enzyme preparation (19.8 mg 175 and $120 \mathrm{mg}$ lyophilized and immobilized enzyme, respectively, packed between two glass wool layers), by means of two 2-3-way valves (6604, Bürkert, $\mathrm{GmbH}$, Germany). The lowering of the water content in the mixture due to its adsorption by the packed bed was monitored by the humidity sensor. The adsorption isotherm was generated by repeating the 180 aforementioned procedure in a stepwise manner for humidity levels from 
$10 \% \mathrm{RH}$ to $90 \% \mathrm{RH}$. The desorption isotherm was acquired by the reverse procedure, i.e. by decreasing the humidity level stepwise from $90 \% \mathrm{RH}$ to $10 \% \mathrm{RH}$. The operation of the water adsorption unit and data retrieval was achieved using a LabView (National Instruments, Texas, USA) program. The

185 cumulative errors involved in the water adsorption measurement did not exceed $1 \%$ for the measurement of the lyophilized enzyme and $15 \%$ for the immobilized preparation.

The water adsorption was modeled using the Brunauer-Emmett-Teller (BET) [18] gas adsorption equation:

190

$$
\frac{a_{w}}{\left(1-a_{w}\right) \cdot M}=\frac{1}{M_{0} \cdot C}+\frac{a_{w} \cdot(C-1)}{M_{0} \cdot C}
$$

where $M$ is the moisture content (in $\% \mathrm{w} / \mathrm{w}$ dry solid), $M_{0}$ is the monolayer water coverage, $a_{w}$ is the water activity and $C$ a constant. From the linear regression of the plot of $a_{w} /\left(\left(1-a_{w}\right) M\right)$ versus $a_{w}$, the theoretical monolayer water coverage can be calculated:

195

$$
M_{0}=\frac{1}{(S+I)}
$$

where $S$ is the slope and $/$ is the y-intercept [19].

\subsection{Enzymatic gas/solid reactor}

The adsorption measurements of the two reaction substrates, acetophenone and 2-propanol, were conducted in the gas/solid reactor [17]. During the 
adsorption experiments no reaction took place. This was achieved due to the absence of water in the adsorption measurements of individual substrates. In the case of competitive adsorption studies, with water present, the enzyme preparation was thermally treated before use $\left(30 \mathrm{~min}\right.$ at $\left.105^{\circ} \mathrm{C}\right)$.

205 A gas mixture with a volumetric flow rate of $15 \mathrm{~mL} / \mathrm{min}$, unless otherwise stated and a defined substrate thermodynamic activity was generated and equilibrated through the bypass. Subsequently, the mixture was directed through the reactor tube containing the deposited enzyme preparation (120 $\mathrm{mg}$ and $565 \mathrm{mg}$ for acetophenone and 2-propanol adsorption studies,

210 respectively, unless otherwise stated). The retention of the compound in the bed due to adsorption was monitored using an online GC and the adsorbed amount was integrated according to the trapezium rule. The procedure was repeated for stepwise increased substrate activities in the gas mixture. The substrates adsorption measurement involved cumulative negative errors of up 215 to $10 \%$.

\subsection{Online gas chromatography}

The outlet of the reactor was directly connected to an online gas chromatograph (Fisons GC 8000, S+H Analytik, Germany). Sampling was 220 performed via a six-way Valco valve (VICI AG International, Switzerland) maintained at $150^{\circ} \mathrm{C}$. The gas chromatograph was equipped with an FID detector, maintained at $250^{\circ} \mathrm{C}$ and a split/split less injector, maintained at 
$200^{\circ} \mathrm{C}$. The separation was realized through a CP-WAX 52CB $(50 \mathrm{~m} \times$ $0.25 \mathrm{~mm} \times 0.2 \mu \mathrm{m}$ ) GC column (Agilent Technologies, Germany) at the 225 following temperature program: $2 \mathrm{~min}$ at $60^{\circ} \mathrm{C}, 40^{\circ} \mathrm{C} / \mathrm{min}$ up to $100^{\circ} \mathrm{C}$, $60^{\circ} \mathrm{C} / \mathrm{min}$ up to $220^{\circ} \mathrm{C}$ and $3 \mathrm{~min}$ at $220^{\circ} \mathrm{C}$. 


\section{Results and discussion}

\subsection{Water adsorption to lyophilized enzyme}

Initially, the water adsorption to lyophilized LBADH was studied and the water

250 adsorption isotherm (Fig.3) was obtained. The water adsorption isotherm follows a pattern resembling the BET isotherm. Despite the fact that the assumptions of the BET theory (for non-polar adsorbate and inert surfaces) are not valid for the protein-water system studied, the model is employed, without conferring the physical meaning to the respective hydration 255 parameters calculated.

Using the linear regression of the BET equation, the amount of water adsorbed, corresponding to the monolayer water coverage of the BET theory, was calculated to $0.0865 \mathrm{mg}_{\text {water }}\left(\mathrm{mg}_{\text {dry protein }}\right)^{-1}$. This value is in the same order of magnitude as the one reported for pharmaceutical proteins [19] and 260 various other proteins [20].

The water adsorption isotherm of lyophilized LBADH differs significantly from the one of the yeast alcohol dehydrogenase (YADH) reported in previous studies: water adsorption to LBADH follows the pattern of the BET adsorption isotherm, whereas to YADH follows the Huttig isotherm pattern [2]. LBADH 265 also has much higher amounts of water adsorbed at water activity levels 
above 0.7 , whereas the calculated amount corresponding to the monolayer water coverage, according to BET theory, is significantly lower than that of YADH (0.35 $\left.\mathrm{mg}_{\text {water }} / \mathrm{mg}_{\text {protein }}\right)$ [2]. The water adsorption isotherm of the lyophilized enzyme powder depicts the capacity of the specific enzyme to 270 adsorb water and depends on the amino acid composition of the protein and the polar side chains of the amino acid residues $[12,18]$ as well as the salts used during the lyophilization of the enzyme, in this case in an amount of $60 \% \mathrm{w} / \mathrm{w}$. However, it provides no further information on the enzyme behavior in the gas/solid system. For this reason the adsorption behavior of the 275 deposited enzyme preparation was further investigated.

\subsection{Water adsorption by the deposited enzyme}

The adsorption isotherm of the total deposited LBADH preparation (carriers with deposited enzyme, containing salts and sucrose) was obtained in

280 replicate (Fig.4). The amount of adsorbed water is referred to as amount of water per protein amount, for facilitating the representation. Nevertheless the amounts measured represent the cumulative adsorbed water by the immobilized preparation, including the enzyme-carriers, sucrose and salts used during the enzyme purification and immobilization. These components 285 influence the water adsorption very strongly [21]. A subtraction of the adsorption isotherm of plain carriers, in order to eliminate their effect, was not 
considered appropriate due to the unknown distribution of the deposited enzyme on the carriers' surface.

The close proximity of the two isotherms indicates that the water adsorption 290 measurement is reproducible, with a maximal error of $1 \%$. Similar to the lyophilized LBADH, the adsorption isotherm also follows the pattern of the BET model. The water activity level above which water ceases being strongly adsorbed by the immobilized preparation (point B, Fig.1) was identified to be slightly higher than 0.5 . For LBADH, it has been previously shown that it is

295 preferable to operate the reaction system at water activities exceeding 0.5 in order to achieve increased conversion in the gas/solid reactor [15]. This implies that higher conversion in the reaction system is actually achieved at a water activity level where only weaker adsorptive interactions with water occur.

\subsection{Effect of sucrose on water adsorption}

The beneficial effect of sucrose on the stability of the LBADH during the deposition process as well as on the storage and operational stability of the enzyme preparation has been shown previously [11, 15]. The effect of sucrose on the water adsorption to the deposited enzyme preparation has been, therefore, investigated here (Fig.5). For water activity levels exceeding the value of 0.5 , the presence of sucrose in the enzyme preparation resulted in an increased amount of water adsorbed per unit of enzyme preparation 
(Fig.5A). The hygroscopic nature of sucrose is responsible for the attraction

310 of more water.

When comparing the two enzyme preparations, with and without sucrose, with respect to water adsorbed per unit of protein, the two curves were inverted (Fig.5B). This is due to the lower protein loading of the sucrose-free material, during the deposition process (protein loading of 0.00074

$315 \mathrm{mg}_{\text {protein }} / \mathrm{mg}_{\text {beads }}$ ), compared to the protein loading achieved in the case of sucrose containing material (protein loading of $0.00275 \mathrm{mg}_{\text {protein }} / \mathrm{mg}_{\text {beads }}$ ). As a result in the case of sucrose being present, more protein "sees" less water.

\subsection{Hysteresis}

320 The fact that the amount of water adsorbed by proteins when the equilibrium is approached from the "wet" side is higher than the amount of water adsorbed when the equilibrium is approached by the "dry" side has already been demonstrated [22]. This hysteresis has already been observed [2,13,2224] and was therefore compared in the current study between the lyophilized 325 and the deposited enzyme preparation.

The adsorption and desorption isotherms do not coincide for the lyophilized enzyme (Fig.6).

The phenomenon of hysteresis is thought to occur due to alterations of the intra- and inter-molecular interactions of protein molecules during the 330 hydration process [12,25]. Hysteresis has also been attributed to the 
formation of hydrates during the protein hydration process. These hydrates persist at lower humidity levels during the desorption process [22]. In the case of LBADH it was found that water could not be desorbed entirely, even after drying the protein for many hours with anhydrous $\mathrm{N}_{2}$ (data not shown). An

335 unexpectedly high amount of irreversibly bound water of $0.6 \mathrm{mg}$ water $/ \mathrm{mg}_{\text {protein }}$ was measured. This may be attributed partly to the protein itself and partly to the TEA buffer contained in the lyophilized enzyme $(60 \% \mathrm{w} / \mathrm{w})$. Observation of lyophilized protein particles that have adsorbed water revealed formation of agglomerates that appeared rigid and probably able to retain water.

340 Regarding the deposited enzyme preparation, both with and without sucrose, the hysteresis was even more prominent (Fig.7), amounting in a difference between adsorption and desorption isotherm of up to $7 \mathrm{mg}_{\text {water }} / \mathrm{mg}_{\text {protein, }}$, for the enzyme deposited with sucrose and $12.5 \mathrm{mg}$ water $/ \mathrm{mg}_{\text {protein }}$ for the one without sucrose.

345 The methodology followed for the construction of the adsorption and desorption isotherms, involving the summation or subtraction of the adsorbed or desorbed respectively water amounts, on each activity level, caused error magnification. This was less pronounced for the adsorption isotherm, where the largest error at highest water activities amounted to less than $2 \%$. 350 However, in desorption, the errors increased predominantly at lower water activities and that led to an approximately $15 \%$ error in the determination of 
the irreversibly bound water. This error, though large, does not change the overall shape of the adsorption and desorption isotherms.

In order to gain insight into the causes of hysteresis, SEM pictures of the

355 enzyme preparations were taken. The glass carriers with the enzyme coating were observed before and after measuring the water adsorption (Fig.8). The enzyme distribution on the carriers' surface was dramatically modified during the process. The initially smooth layer of enzyme (Fig.8A and Fig.8C) was lost as the enzyme seemed to have been partly washed away from the carrier

360 surface. Material bridges appeared between the individual carriers (Fig.8B) and clear areas on the carriers' surface were revealed (Fig.8D). This suggests that the biocatalyst is leached from the enzyme preparation to the glass wool layers.

This is supported by the protein loading of the deposited preparation that was

365 reduced to an approximately $30 \%$ lower value compared to that of the initial protein loading of the preparation. In the case of sucrose being absent during the immobilization the reduction of the protein loading was even more pronounced, reaching a level of around $45 \%$. It appears that sucrose acts as a stabilizer for the attached enzyme on the carriers' surface.

\subsection{Acetophenone adsorption to the packed bed with deposited enzyme}

So far, substrate adsorption in solid/gas biocatalysis has been widely neglected. Therefore, the effect of the enzyme on the adsorption of 
acetophenone by the packed bed was here studied using dynamic 375 experiments (Fig.9). After turning the flow from the bypass to the packed bed, the partial pressure of acetophenone dropped as a result of its adsorption by the bed and a negative peak was observed over hours. In a theoretical prediction the residence and response time of the substrate (acetophenone or 2-propanol) at the outlet of the reactor was estimated to be in the range of a 380 few seconds.

It was found that the amount of the adsorbed acetophenone to the carriers when enzyme was deposited on the surface was $35 \%$ higher compared to the adsorbed amount to the plain glass carriers. The acetophenone adsorption isotherm was measured within the acetophenone activity range relevant to

385 the operation of the gas/solid reactor $\left(a_{A c P h}=0.05-0.32\right)$ (Fig.10). Following a similar practice as in the case of water adsorption by the deposited enzyme preparation, the amount of adsorbed acetophenone is referred to as amount of acetophenone per protein amount, for facilitating the representation.

Errors involved in the acetophenone adsorption measurements led mainly to 390 underestimation of the adsorbed acetophenone amount (due to limited tailing) that summed up to $10 \%$, at the highest acetophenone activities.

The amount of acetophenone adsorbed by the immobilized enzyme preparation is very low for acetophenone activities below 0.1 . Above this activity level it shows an almost linear increase. By comparing the adsorption 395 isotherms of acetophenone and water (Fig.4) for the same range of activities 
it is clear that: (a) the pattern of the two isotherms is different; unlike the water adsorption isotherm, the acetophenone adsorption isotherm does not follow the BET pattern and (b) the mass of adsorbed acetophenone is higher than the mass of adsorbed water at the same levels of thermodynamic activity. At

400 the highest acetophenone activity level tested, namely $a_{\mathrm{AcPh}}=0.32$, the adsorbed acetophenone amount reached a value of $6 \mathrm{mg} \mathrm{AcPh} / \mathrm{mg}_{\text {protein. }}$. This amount of water is adsorbed only at water activity levels above 0.6 . In terms of mole amounts, the adsorbed amount of water is almost double the adsorbed amount of acetophenone $\left(0.091 \mathrm{mmol}\right.$ water $/ \mathrm{mg}_{\text {protein }}$ versus 0.05 $\left.405 \mathrm{mmol}_{\mathrm{AcPh}} / \mathrm{mg}_{\text {protein }}\right)$, for the same level of thermodynamic activity of the two compounds, namely 0.32 .

\subsection{2-propanol adsorption to the packed bed with deposited enzyme.}

The adsorption of the second substrate, 2-propanol, to the deposited enzyme

410 preparation in the gas/solid reactor was also investigated. In the dynamic experiment, gas mixtures of nitrogen and 2-propanol, with thermodynamic activities in the range of $\mathrm{a}_{2 \text {-prop }}=0.079-0.38$, were directed through the packed bed but no negative peaks were detected (Fig.11). The GC sampling of the mixture took place only 6 min after the flow was switched from the bypass to 415 the reactor. Even if adsorption of this compound occurred, it was not detectable in the specific set-up. 


\subsection{Competitive adsorption of substrates and water}

A potential effect of water on the adsorption of acetophenone and 2-propanol

420 to the deposited enzyme preparation for a common water activity level for the reaction mixture in the gas/solid reactor of 0.54 was also investigated. All other parameters were kept at the same level as those in the investigation of the substrate adsorption without water in the mixture. The enzyme preparation was thermally treated, aiming at the cofactor deactivation

425 assuming that this short thermal treatment did not severely alter the enzyme capacity to adsorb water.

By comparing the adsorption isotherms of acetophenone in Fig.10 it is obvious that the presence of water in the gas mixture leads to a decrease in the amount of acetophenone adsorbed by the enzyme. The substrate and 430 water molecules compete for adsorption sites of the deposited catalyst and that leads to a lower acetophenone adsorption. On the other hand, the presence of acetophenone molecules may also influence water adsorption. According to [2] however, due to the low polarity of the acetophenone this effect is not expected. Due to the incompatibility of the humidity sensors with

435 acetophenone, the respective competitive adsorption studies could not be performed.

Under the assumption that the water adsorption isotherm is not strongly influenced by the adsorption of acetophenone, the quantity of adsorbed water, at $a_{w}=0.54$, was obtained from the water adsorption isotherm (Fig.4). 
440 Similarly, the quantity of adsorbed acetophenone, at $\mathrm{a}_{\mathrm{AcPh}}=0.22$, was also calculated. The ratio of adsorbed water moles to adsorbed acetophenone moles was found to be approximately $12.5\left(0.183 \mathrm{mmo} \mathrm{l}_{\text {water }} / \mathrm{mg}_{\text {protein }}\right.$ versus $\left.0.015 \mathrm{mmol} \mathrm{acph}_{\mathrm{mg}} / \mathrm{mg}_{\text {proin }}\right)$, at the above mentioned water and acetophenone activity levels, which are typical values for the reactor operation. Taking into 445 account the molecular weight of the LBADH $(106 \mathrm{kDa})$, it is estimated that, at these conditions, 1 molecule of protein is surrounded by 19400 molecules water and 1560 molecules acetophenone.

As it is shown in Fig.11B, the presence of water did not influence the adsorption behavior of 2-propanol. Once again, 2-propanol adsorption by the 450 immobilized enzyme preparation was not detectable in the dynamic experiment, exactly as in the case of water being absent. 


\section{Concluding remarks}

In the gas/solid enzymatic reactor, thermodynamic equilibrium is highly controlled by adjusting the carrier gas composition. While hydration of the 455 enzyme has been studied previously, no study had fully covered the adsorption of all compounds to the enzymatic fixed bed.

A simple and efficient experimental set-up, the water adsorption unit, has been used to monitor the water adsorption to the deposited LBADH, at conditions resembling those of the continuous gas/solid reactor. The 460 hydration of the deposited enzyme has been described by a BET-like isotherm. The critical thermodynamic water activity level, above which the system deviates from the initial adsorption behavior, has been found to be approximately 0.5 . It has been shown that the presence of sucrose in the enzyme preparation has an important influence on the capacity of the packed

465 bed to adsorb and retain water. It has been also shown that the hysteresis during water desorption from the deposited preparation is very significant. This is accompanied by micro-structural changes of the lyophilized or deposited enzyme preparations, suggesting the choice of covalent immobilization methods in the future. The adsorption of the two substrates of

470 the LBADH, acetophenone and 2-propanol, has been investigated for the first time, at conditions mimicking those of a reacting system, allowing a more complete insight on the microenvironment of the deposited enzyme. It has 
been revealed that although 2-propanol does not get adsorbed at a level, detectable at the specific set-up, acetophenone, on the other hand, is 475 adsorbed to the deposited enzyme preparation at a significant level, comparable to the amount of adsorbed water. This might lead to mass transfer limitations due to diffusional transport to the enzyme. Therefore the overlaying phenomena of adsorption and reaction kinetics will be the topic of future studies. 


\section{Acknowledgements}

This work was performed within the graduate school "BioNoCo" (Biocatalysis using non-conventional media), funded by DFG (German Research Foundation). The authors would like to express their gratitude to Ms. Kulishova from the Institute of Molecular Enzyme Technology, Heinrich Heine 485 University Düsseldorf (IMET) at Research Center Jülich, for the expression, purification and lyophilization of the LBADH and to Dr. Pfaff and Ms. Göths from the Institute of Material Applications for Mechanical Engineering (IWM) at RWTH Aachen University for the SEM pictures.

490

495 


\section{References}

[1] Uchiyama, H., Oguri, K., Yagi, O., Kokufuta, E., Trichloroethylene degradation by immobilized resting cells of Methylocystis sp. in a gassolid bioreactor. Biotechnol. Lett. 1992, 14, 619-622.

[2] Yang, F., Russell, A. J., The role of hydration in enzyme activity and stability: 1. Water adsorption by alcohol dehydrogenase in a continuous gas phase reactor. Biotechnol. Bioeng.1995. 49, 700-708.

[3] Lamare, S., Legoy, M. D., Graber, M., Solid/Gas Bioreactors: Powerful Tools for Fundamental Research and Efficient Technology for Industrial Applications. Green Chem. 2004, 36, 445-457.

515 [4] Drapon, R., Enzyme activity as a function of water activity, in: D. Simatos and J.-L. Multon, Editors, Properties of Water in Foods, Nyhoff, Dordrecht, The Netherlands 1985, pp. 171-190.

[5] Barzana, E, Klibanov, A, Karel, M., Enzyme-catalyzed, gas-phase reactions. Appl. Biochem. Biotechnol. 1987, 15, 25-34. 
[6] Robert, H., Lamare, S., Parvaresh, F., Legoy, M., The role of water in gaseous biocatalysis, in: Tramper, J., Vermue, M. H., Beeftink, H. H., Von Stockar, U., Biocatalysis in Non-conventional Media, Elsevier Science Publ., Amsterdam, The Netherlands 1992, pp. 85-92.

[7] Yang, F., Russell, A. J., The role of hydration in enzyme activity and stability: 2. Alcohol dehydrogenase activity and stability in a continuous gas phase reactor. Biotechnol. Bioeng. 1995, 49, 709-716.

[8] Trivedi, A. H., Spiess, A. C., Daussmann, T., Büchs, J., Study on Mesophilic and Thermophilic Alcohol Dehydrogenases in Gas-Phase Reaction. Biotechnol. Prog. 2006, 22, 454-458.

[9] Hidaka, N., Matsumoto, T., Gaseous Ethanol Oxidation by Immobilized Enzyme in a Packed Bed Reactor. Ind. Eng. Chem. Res. 2000, 39, 909-915.

[10] Perez, V. H., Miranda, E. A., Valenca, G. P., Kinetics of Gas-Phase Hydrolysis of Ethyl Acetate Catalyzed by Immobilized Lipase. Appl. Biochem. and Biotechnol. 2007, 136, 23-37. 
[11] Ferloni, C., Heinemann, M., Hummel, W., Daussmann, T., Büchs, J., Optimization of Enzymatic Gas-Phase Reactions by Increasing the 545 Long-Term Stability of the Catalyst. Biotechnol. Prog. 2004, 20, 975978

[12] Hnojewyj, W. S., Reyerson, L. H., Further studies on the sorption of $\mathrm{H}_{2} \mathrm{O}$ and $\mathrm{D}_{2} \mathrm{O}$ vapors by lysozyme and the deuterium--hydrogen exchange effect. J. Phys. Chem. 1961, 65, 1694-1698.

[13] Killion, P. J., Reyerson, L. H., Cameron, B. F., Sorption of H2O and D2O. Vapor by human methemoglobin $A$ and methemoglobin $S$ derivatives, and sperm whale metmyoglobin. J Colloid Interface Sci. 1970, 34, 495-504.

[14] Mellon, E. F, Korn, A. H, Hoover, S. R., Water Absorption of Proteins. II. Lack of Dependence of Hysteresis in Casein on Free Amino Groups. J. Am. Chem. Soc. 1948, 70, 1144-1146.

[15] Trivedi, A. H., Heinemann, M., Spiess, A. C, Daussmann, T., Büchs, J., Optimization of adsorptive immobilization of alcohol dehydrogenases. J. Biosci. Bioeng 2005, 99, 340-347. 
565 [16] Bonde, M., Pontoppidan, H, Pepper, D. S., Direct dye binding-A quantitative assay for solid-phase immobilized protein. Anal. Biochem. 1992, 200, 195-198.

[17] Lamare, S., Legoy, M. D., Solid/gas biocatalysis: How to fully define the system? Biotechnol. Tech. 1995, 9, 127-132.

[18] Brunauer, S., Emmett, P.H., Teller, E., Adsorption of gases in multi molecular layers. J. Amer. Chem. Soc. 1938, 60, 309-319.

575 [19] Costantino, H. R., Curley, J. G., Hsu, C. C., Determining the water sorption monolayer of lyophilized pharmaceutical proteins. J. Pharm. Sci. 1997, 86, 1390-1393.

[20] Pauling, L., The Adsorption of Water by Proteins. J. Am. Chem. Soc. $1945,67,555-557$.

[21] Adlercreutz, P., On the importance of the support material for the enzymatic synthesis in organic media. Support effects at controlled water activity. Eur. J. Biochem. 1991, 199, 609-614. 
[22] Mellon, E. F., Hoover, S. R, Hygroscopicity of Amino Acids and Its Relationship to the Vapor Phase Water Absorption of Proteins. J. Am. Chem. Soc. 1951, 73, 3879-3882.

590 [23] Bryan, W. P., Thermodynamic models for water-protein sorption hysteresis. Biopolymers. 1987, 26, 1705-17016

[24] Sirotkin, V. A., Faizullin, D. A., Interaction enthalpies of solid human serum albumin with water-dioxane mixtures: comparison with water and organic solvent vapor sorption. Thermochimica Acta 2004, 415, 127-133.

[25] McMinn, J. H., Sowa, M.J., Charnick, S. B., Paulaitis, M.E., The hydration of proteins in nearly anhydrous organic solvent suspensions.

600 Biopolymers 1993, 33, 1213-1224. 


\section{Legends}

Figure. 1 Water adsorption isotherm [4].

605 Figure. 2 Water adsorption measurement unit: (1) humidity trap, (2) mass flow controllers, (3) thermo-constant chamber, (4) heating coils, (5) water saturation flasks, (6) mixing chamber, (7) 2-3-way valves, (8) packed bed, (9) humidity sensor.

Figure. 3 Water adsorption isotherm of lyophilized LBADH powder: $m_{\text {enzyme }}=19.8 \mathrm{mg}, V_{\text {tot }}=15$ $610 \mathrm{~mL} / \mathrm{min}, T=40^{\circ} \mathrm{C}$. The insert shows the linearized BET isotherm according to Eq.1.

Figure. 4 Water adsorption isotherm of deposited enzyme preparation with sucrose. $m=120$ $\mathrm{mg}$, protein loading $=0.00275 \mathrm{mg} / \mathrm{mg}, V_{\text {tot }}=15 \mathrm{~mL} / \mathrm{min}, T=40^{\circ} \mathrm{C}$. Open $/$ close symbols refer to the two replicates. The arrow indicates the water activity level above which deviation from the 615 initial adsorption behavior occurs.

Figure. 5 Sucrose effect on the water adsorption of deposited enzyme preparation: $m=120$ $\mathrm{mg}$, protein loading=0.00275 $\mathrm{mg} / \mathrm{mg}$ (with sucrose), protein loading $=0.00074 \mathrm{mg} / \mathrm{mg}$ (without sucrose), $V_{t o t}=15 \mathrm{~mL} / \mathrm{min}, T=40^{\circ} \mathrm{C}$. The water adsorbed is calculated here as water amount 620 adsorbed per $\mathrm{mg}$ of beads of the catalytic bed (A) and as water amount adsorbed per mg of protein $(B)$. The closed circles correspond to enzyme preparations with sucrose and the open ones without.

Figure. 6 Water adsorption and desorption isotherms of lyophilized enzyme: $m_{\text {enzyme }}=19.8$ 625 $\mathrm{mg}, V_{\text {tot }}=15 \mathrm{~mL} / \mathrm{min}, T=50^{\circ} \mathrm{C}$. 
Figure. 7 Adsorption and desorption isotherms of the deposited enzyme preparation with (A) and without $(B)$ sucrose: $m_{\text {enzyme }}=120 \mathrm{mg}$, protein loading=0.00275 $\mathrm{mg} / \mathrm{mg}(A)$, protein loading $=0.00075 \mathrm{mg} / \mathrm{mg}(B), V_{\text {tot }}=15 \mathrm{~mL} / \mathrm{min}, T=40^{\circ} \mathrm{C}$.

630 Figure. 8 SEM pictures of the deposited enzyme with sucrose on glass carriers: $(A)$ and (C) carriers before the water adsorption measurement process; $(B)$ and (D) carriers after the water adsorption measurement process. The material bridges created between the individual carriers are indicated in (B) by arrows.

635 Figure. 9 Effect of enzyme on the acetophenone adsorption capacity of the catalytic bed: $m=565 \mathrm{mg}$, protein loading $=0.0021 \mathrm{mg} / \mathrm{mg}, V_{\text {tot }}=10 \mathrm{~mL} / \mathrm{min}, T=45^{\circ} \mathrm{C}$. Triangles give the acetophenone partial pressure at the packed bed inlet, the open circles the partial pressure at the outlet of a packed bed with plain glass carriers and the closed circles the partial pressure at the outlet of a packed bed with glass carriers coated with deposited enzyme plus sucrose.

Figure. 10 Acetophenone adsorption isotherms for the deposited enzyme preparation (with sucrose): with triangles the adsorption isotherm of the gas mixture without water vapors, with circles the adsorption isotherm with water vapors of $a_{w}=0.54$. For both $m=120 \mathrm{mg}$, protein 645 loading $=0.0021 \mathrm{mg} / \mathrm{mg}, V_{\text {tot }}=15 \mathrm{~mL} / \mathrm{min}, T=40^{\circ} \mathrm{C}$.

Figure. 11 2-propanol equilibration without $(A)$ and with $(B)$ water: $m_{\text {bed }}=565 \mathrm{mg}$, protein loading $=0.0021, V_{\text {tot }}=10 \mathrm{~mL} / \mathrm{min}, T=40^{\circ} \mathrm{C}, a_{w}=54 \%$. Open circles correspond to the flow through the bypass while closed ones flow through the packed bed. 


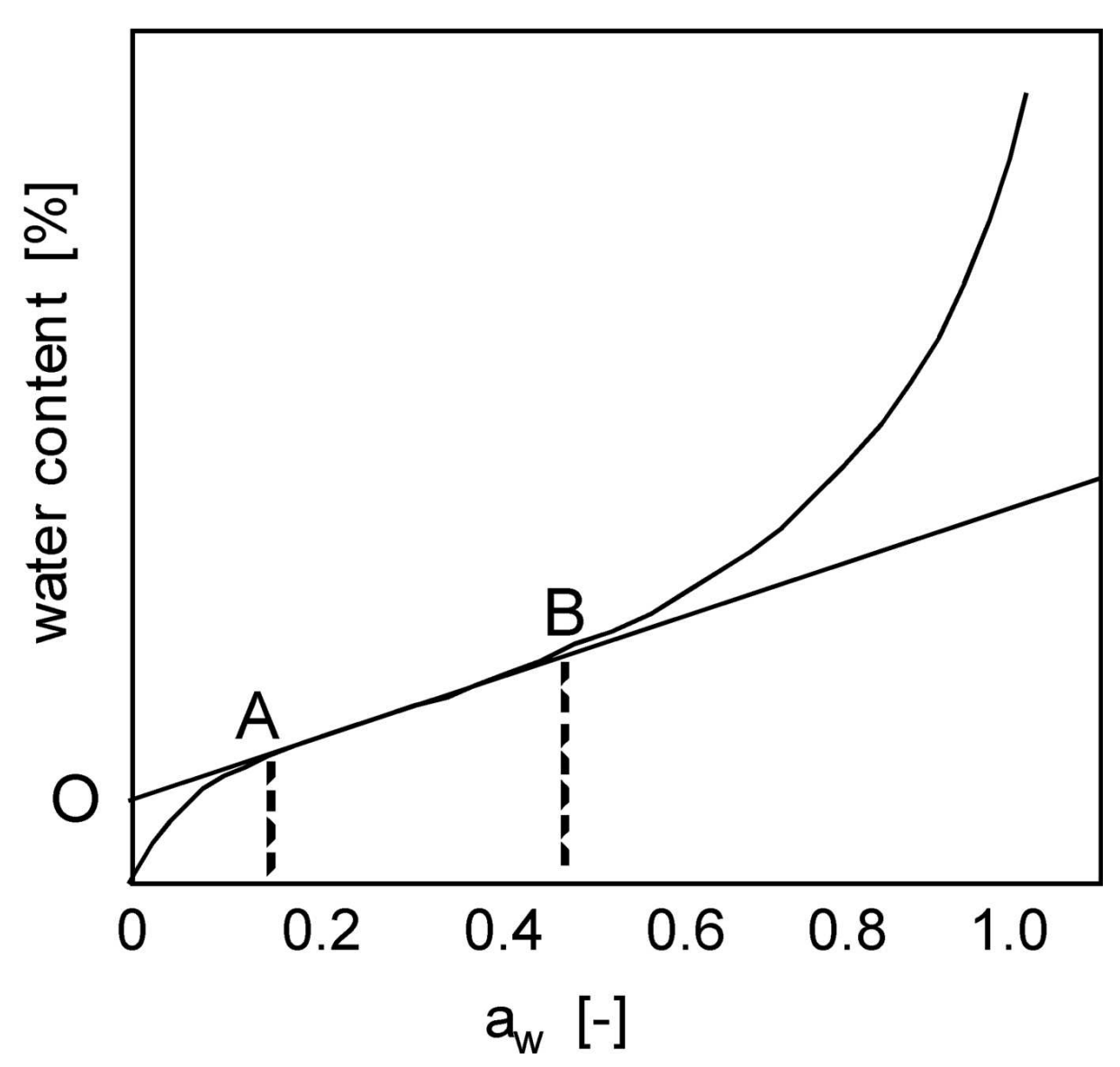

$62 \times 55 \mathrm{~mm}(600 \times 600 \mathrm{DPI})$ 


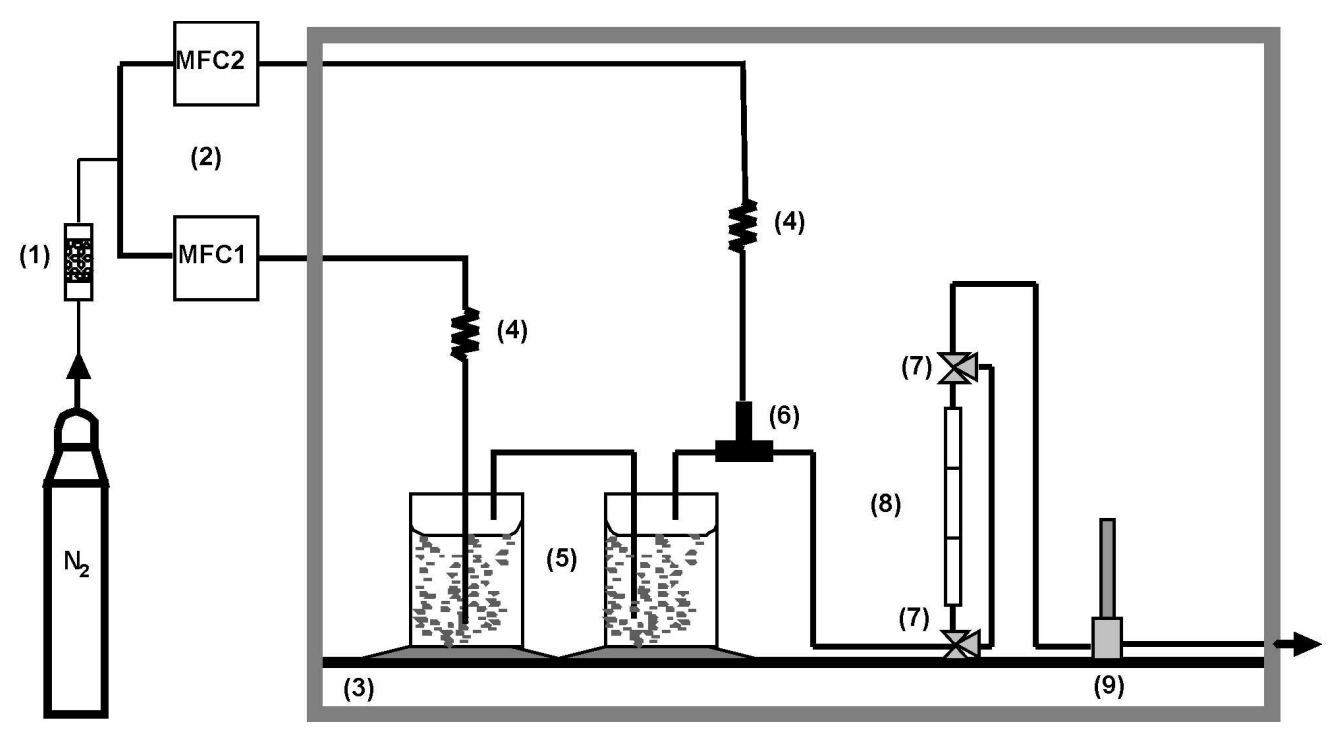

$125 \times 67 \mathrm{~mm}(400 \times 400$ DPI $)$ 


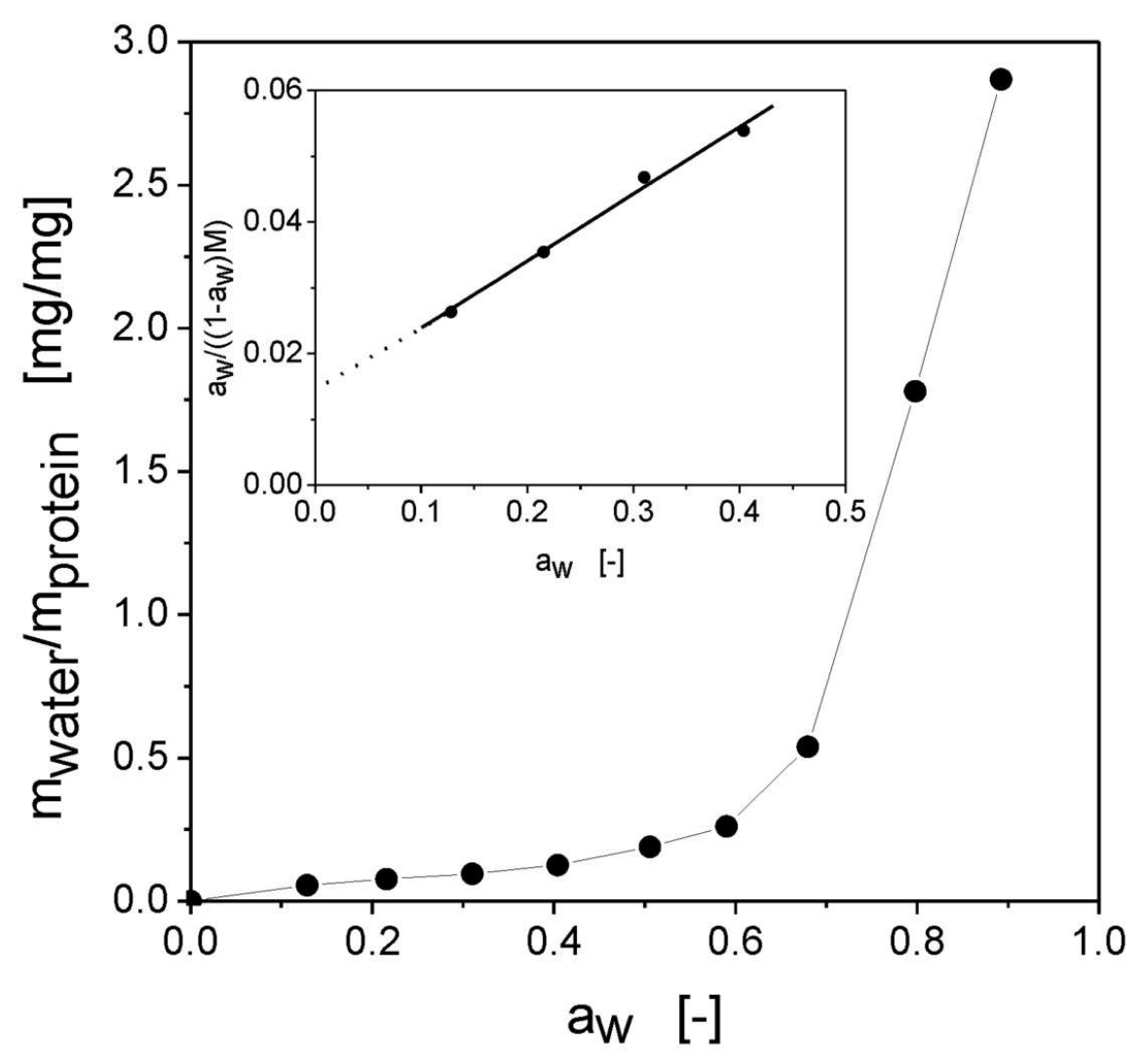

$53 \times 50 \mathrm{~mm}(600 \times 600 \mathrm{DPI})$ 


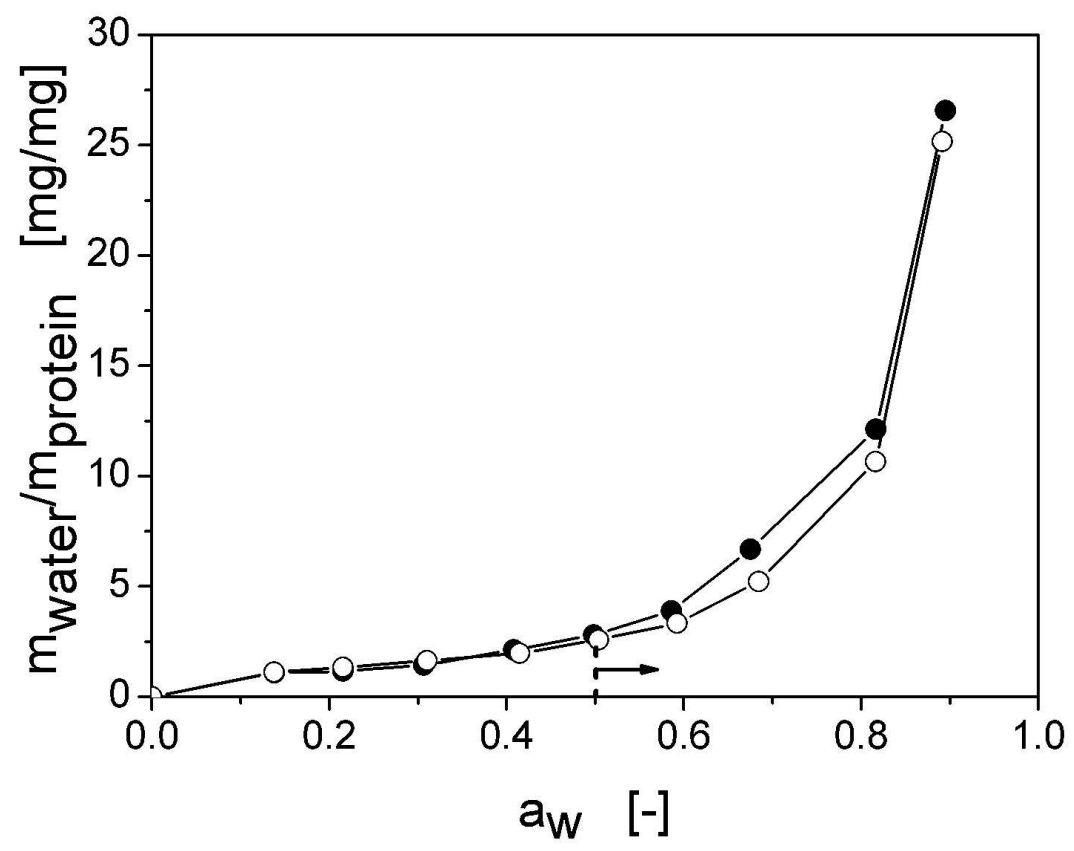

$297 \times 210 \mathrm{~mm}(300 \times 300$ DPI $)$ 


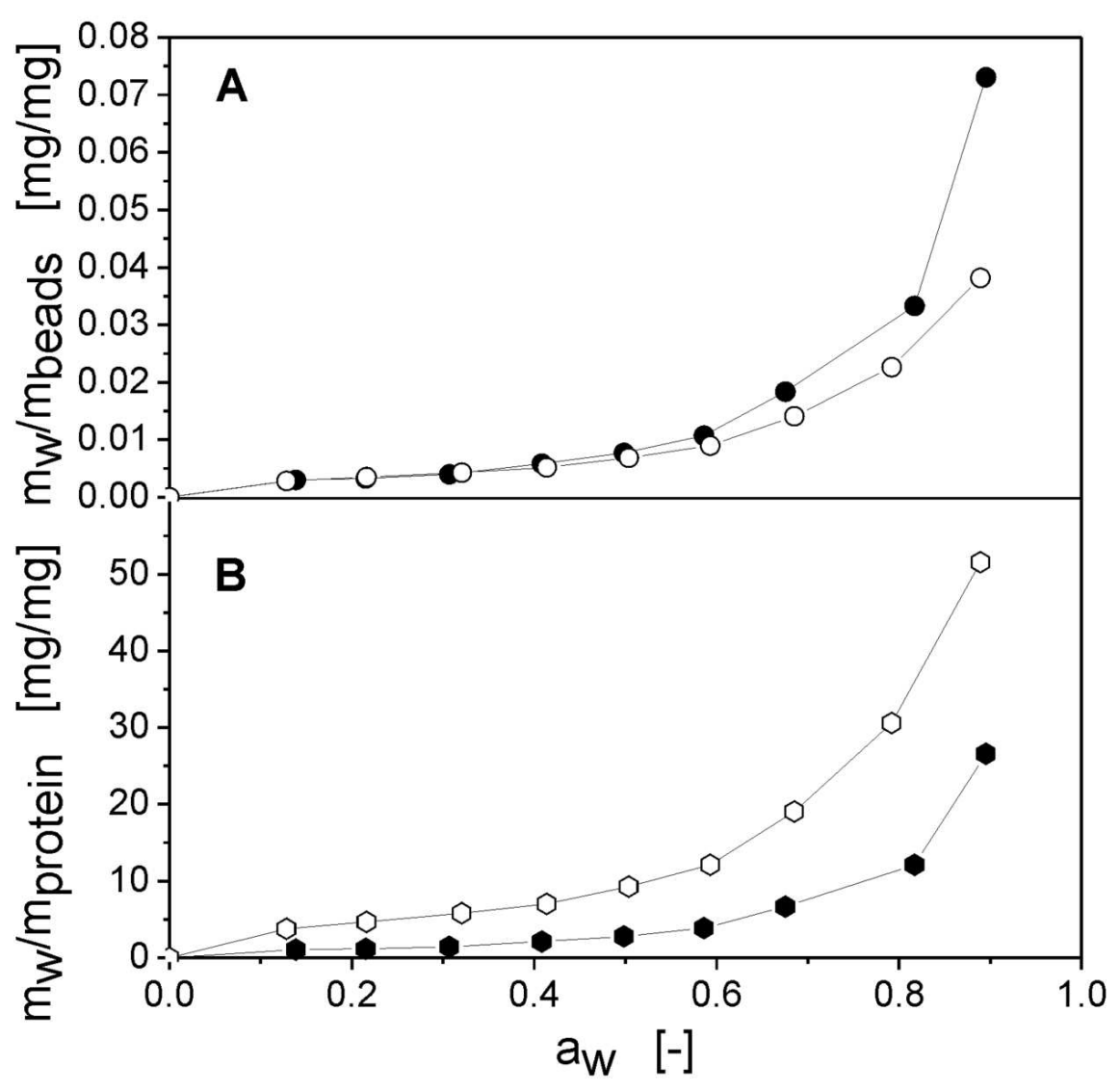

$60 \times 59 \mathrm{~mm}(600 \times 600$ DPI $)$ 


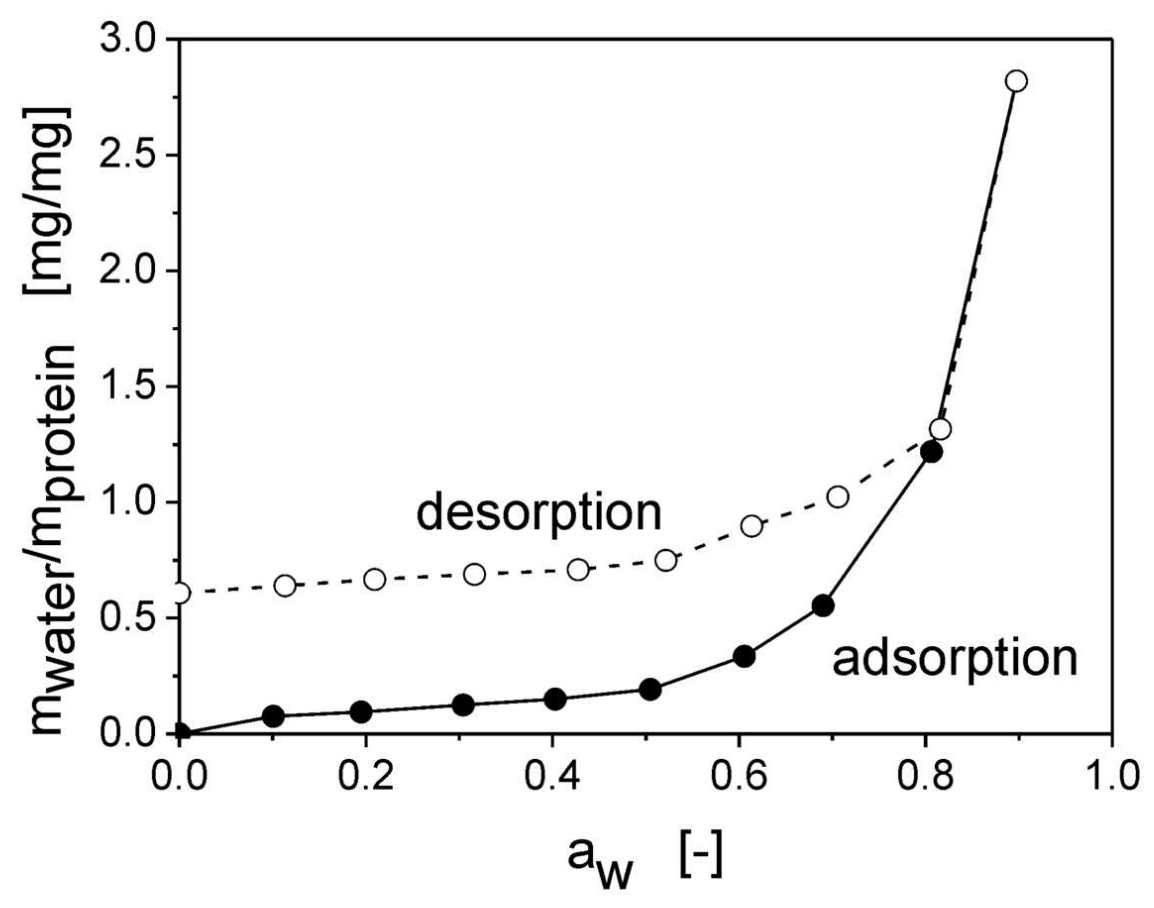

$55 \times 45 \mathrm{~mm}(600 \times 600$ DPI $)$ 


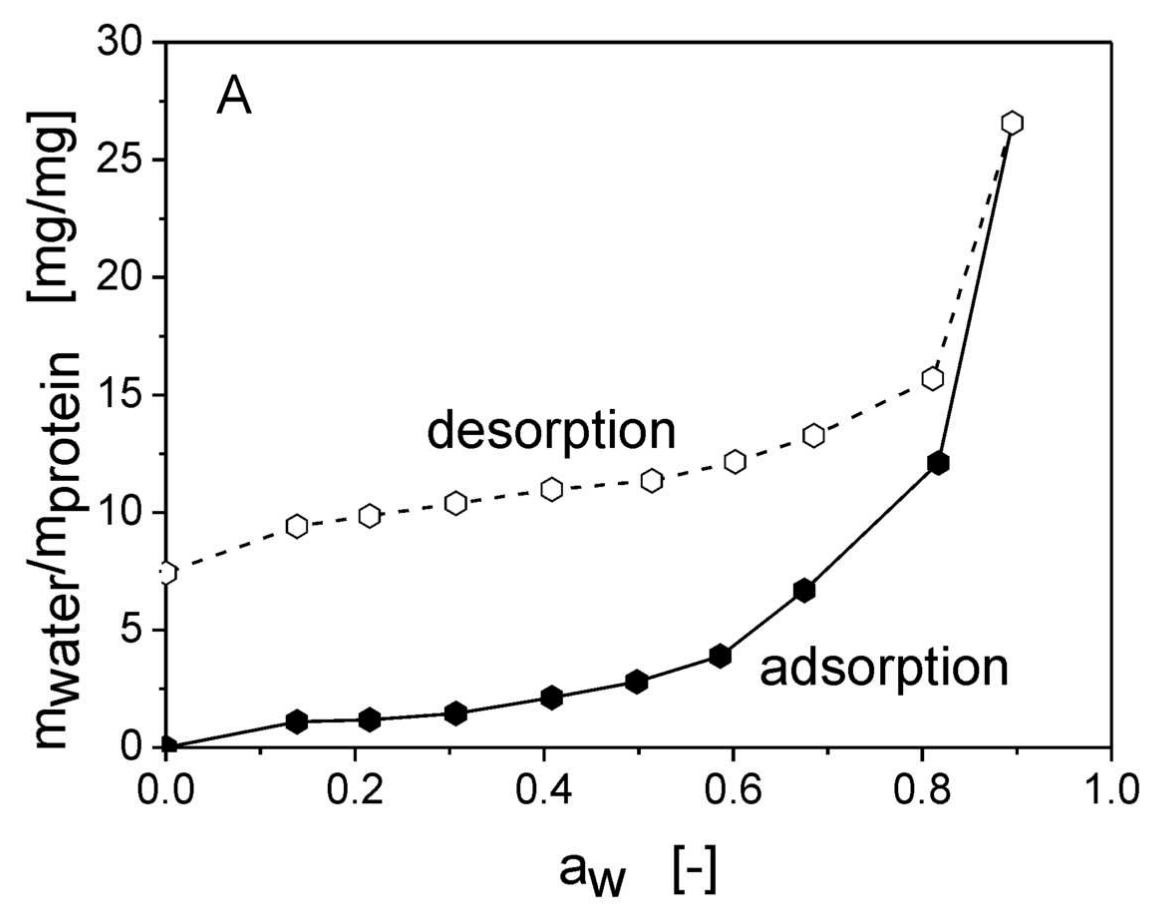

$55 \times 45 \mathrm{~mm}(600 \times 600 \mathrm{DPI})$ 


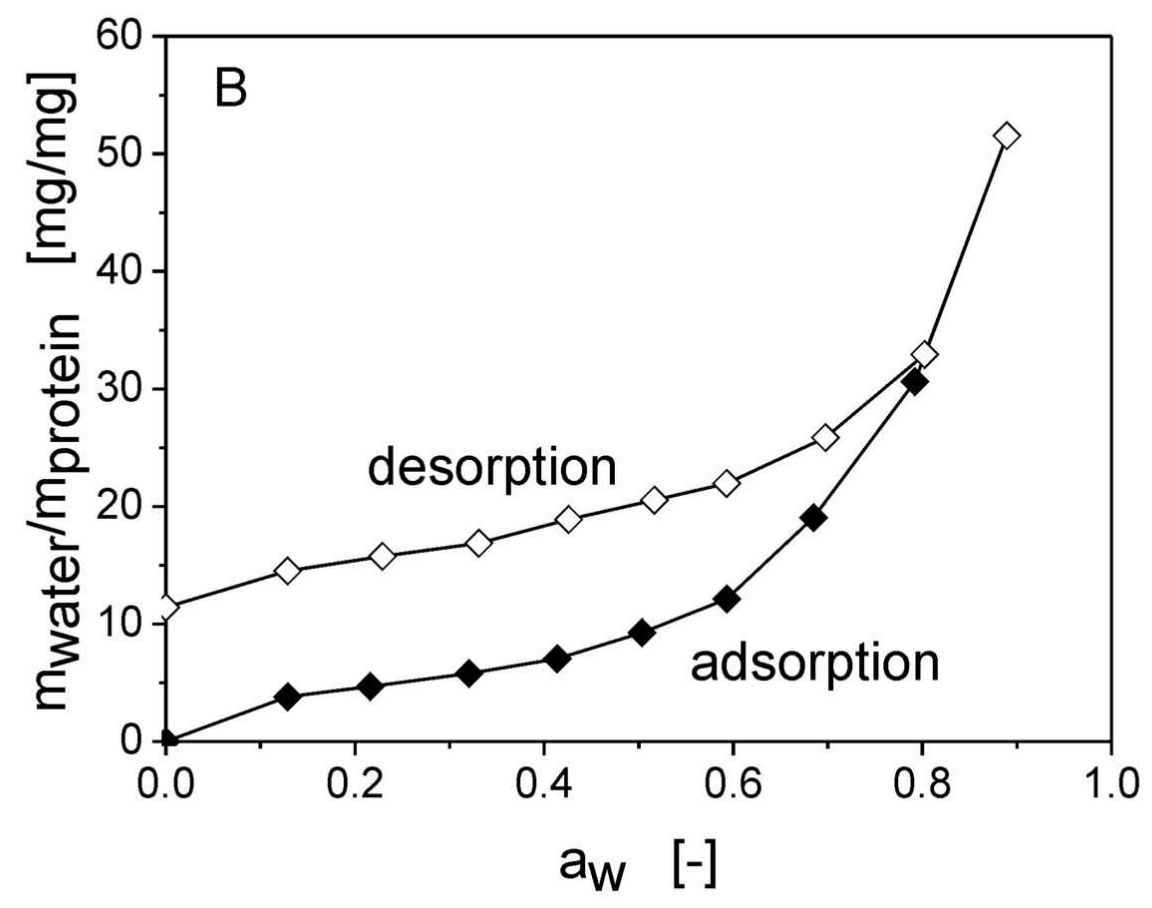

$55 \times 45 \mathrm{~mm}(600 \times 600 \mathrm{DPI})$ 


\section{Page 41 of 44}

1

2

3

4

5

6

7

8

10

11

12

14

15

16

17

18

19

20

21

22

23

24

25

26

27

28

29

30

31

32

33

34

35

36

37

38

39

40

41

42

43

44

45

46

47

48

49

50

51

52

53

54

55

56

57

58

59

60
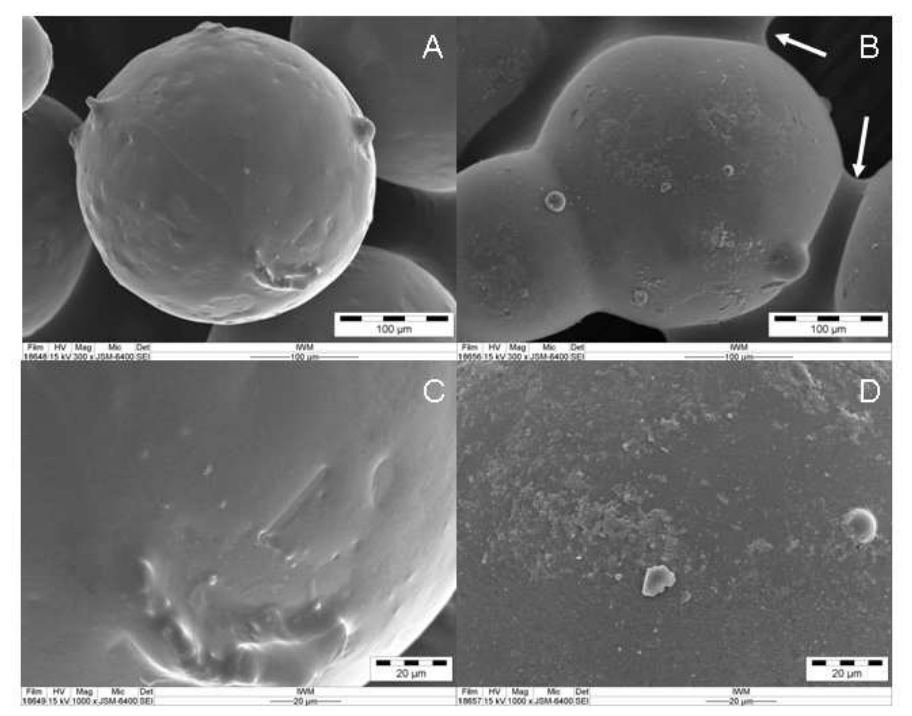

$254 \times 190 \mathrm{~mm}(96 \times 96 \mathrm{DPI})$

Wiley-VCH 


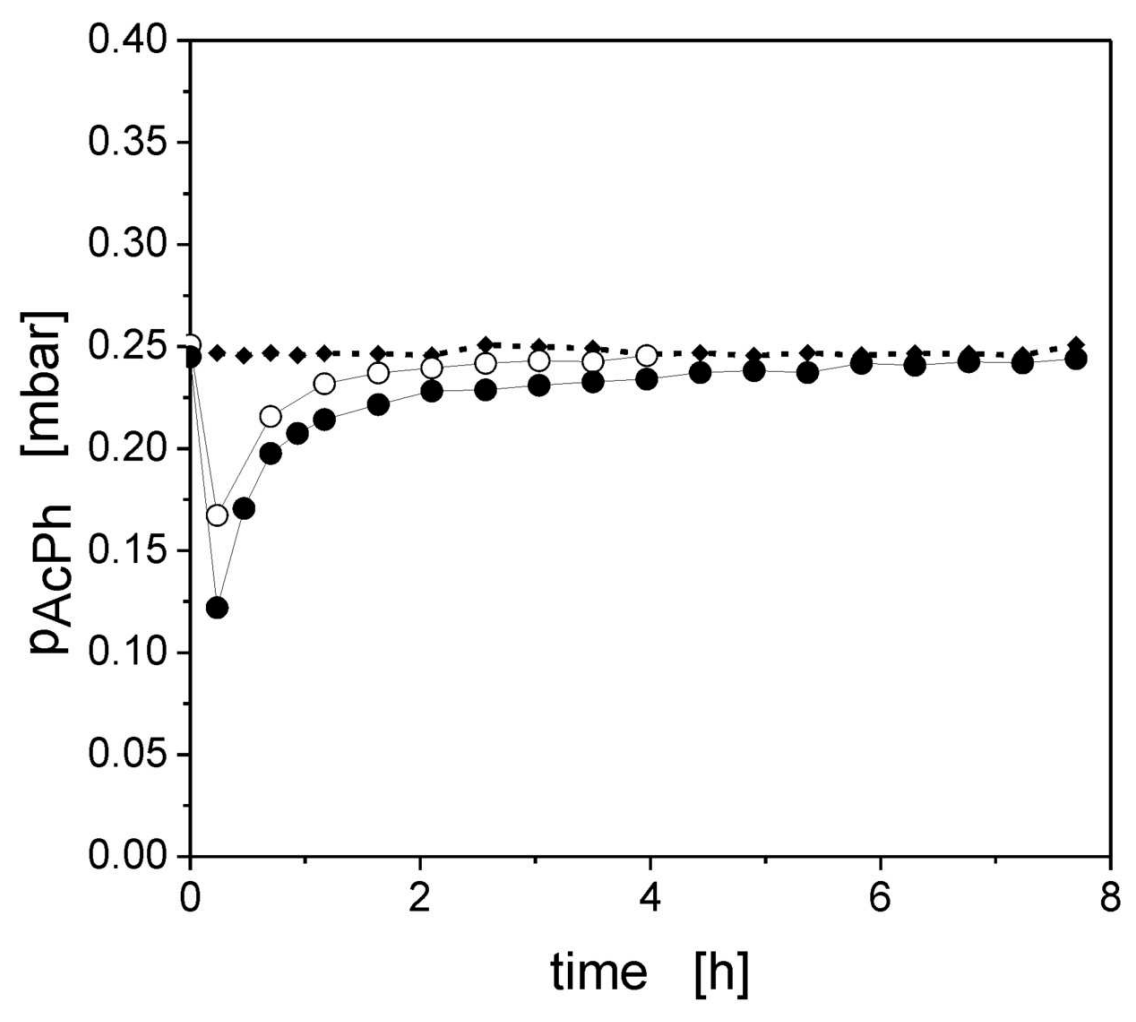

$61 \times 54 \mathrm{~mm}(600 \times 600 \mathrm{DPI})$ 


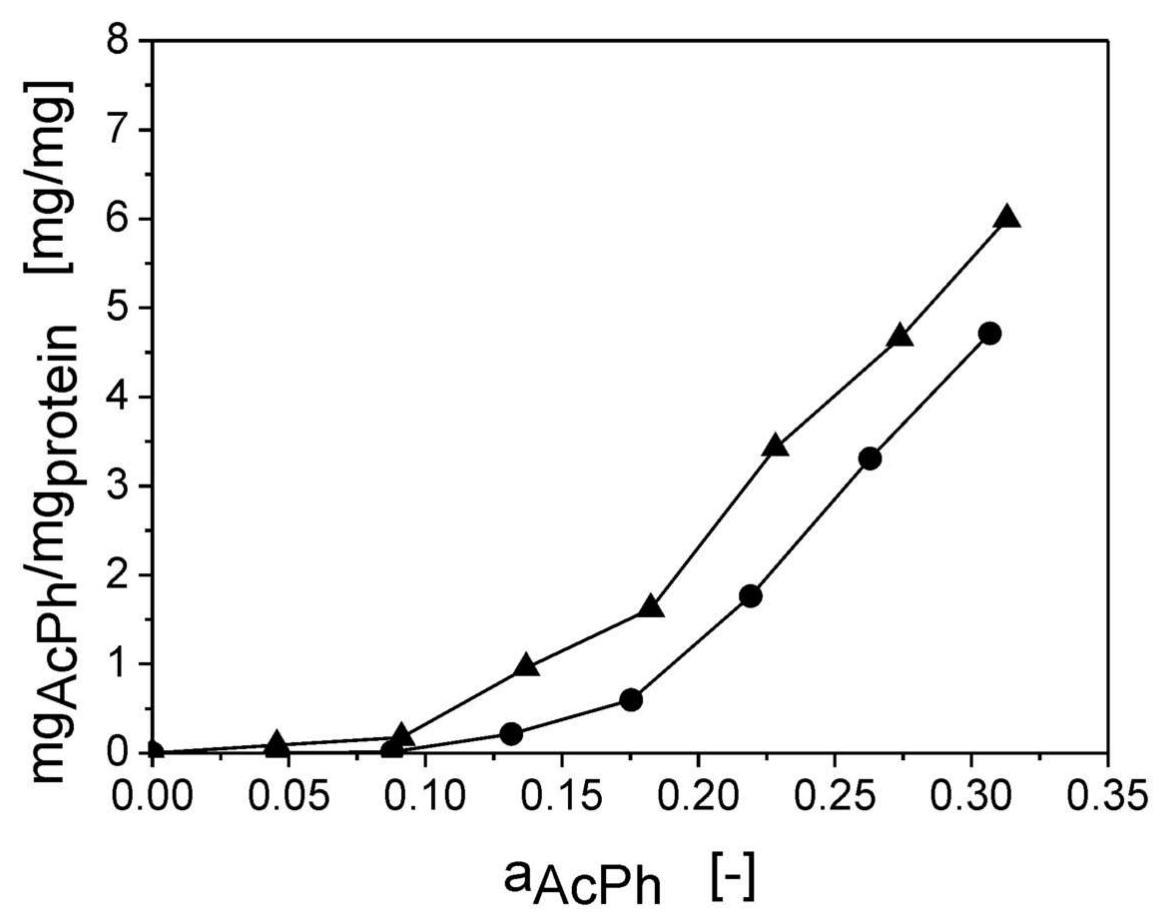

$55 \times 46 \mathrm{~mm}(600 \times 600$ DPI $)$ 


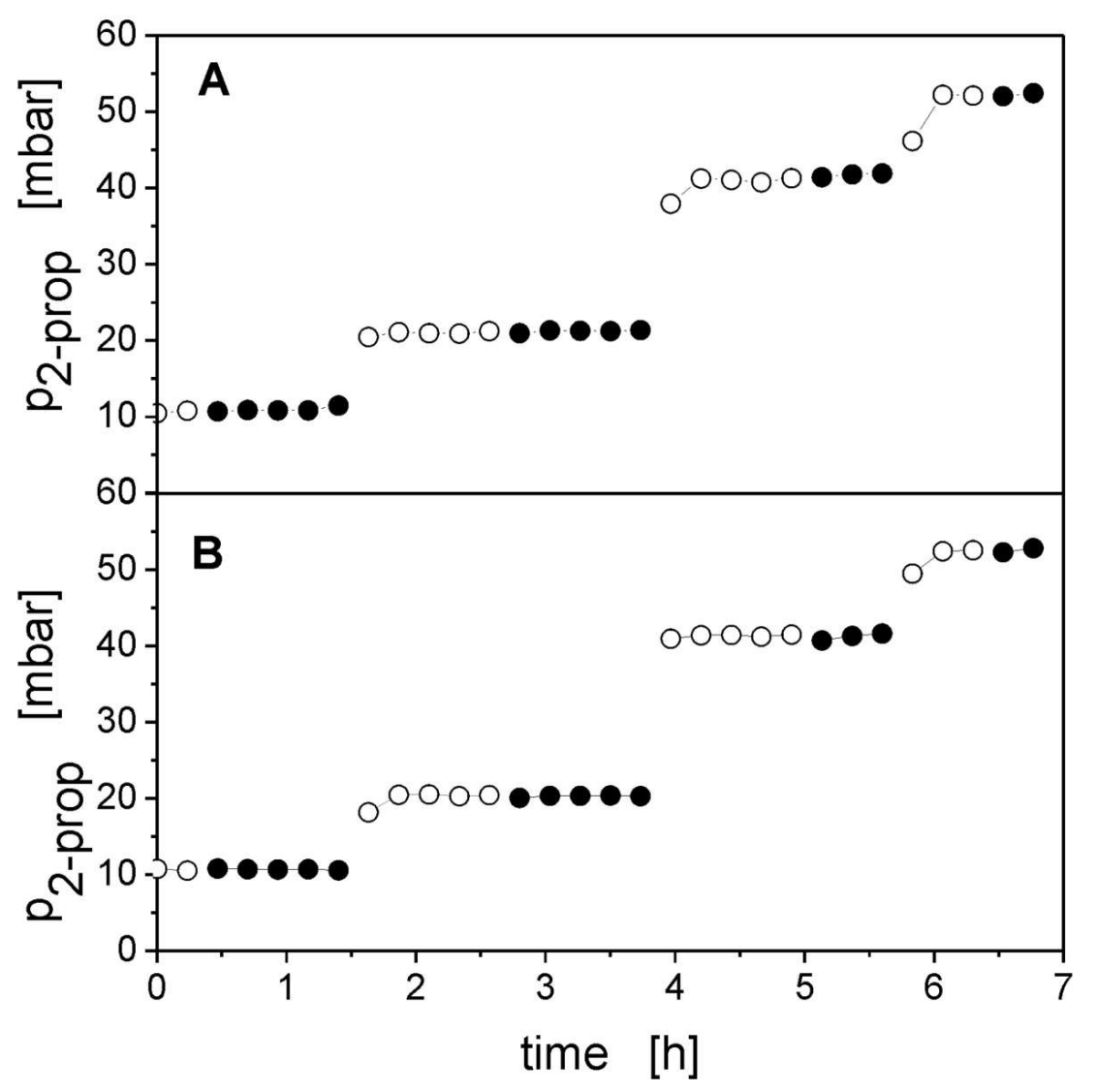

$60 \times 58 \mathrm{~mm}(600 \times 600 \mathrm{DPI})$ 